\title{
Measuring the Financial Performance of Islamic Banks in SELECTED COUNTRIES
}

\author{
Terzi Chokri ${ }^{\star}$, El Ammari Anis $\star \star$ \\ Received date: 10/ 03/2018, Accepted date: 12/06/2018, online publication date: 07/ 12/2018,
}

\begin{abstract}
The object of this paper is to study the theory of the finance and the Islamic banks through their concepts and logics of functioning. We focus on the analysis of the banking performances, in particular in terms of profitability which has a big interest to allow the banks to arrest the factors which act on their profitability and of offering them so better control levers of action, control and forecast. What requires a definition of the internal and external determiners of the profitability of Islamic banks? We suggest approaching this question from the specification and from the estimation of a model which integrates at once organizational, exogenous and macro-financial measurable aspects. The empirical analysis was focused on the determiners of the Islamic banking performance. Our study which concerned 10 Islamic banks in 10 various countries showed essentially that the profitability of asset constitutes the main explanatory variable of the banking performance. The performance is positively correlated with CTA and negatively with ASITA. Concerning the externals factors, the profitability is weakly explained by the rates of inflation and growth.
\end{abstract}

Keywords: Islamic Finance, Islamic Banks, Riba, Chariaa, Performance.

JEL Code: D14, G21, Z12, L25, P27.

Citation: TERZI, C., EL AMMARI, A. (2018). Measuring the Financial Performance of Islamic Banks in Selected Countries. Journal of Finance and Corporate Governance, Vol., 2, No. 1: pp. 7-20. (Jun 2018); ISSN: 2602-5655

\footnotetext{
^Higher Institute of Management University of Gabès, Tunisia E-mail: terisig5@yahoo.fr, Corresponding Author: (+21622658602)

$\star \star$ Faculty of Economic Sciences and Management of Mahdia University of Monastir, Tunisia
} 


\section{Introduction}

The Islamic banking industry appeared and developed in the last two decades. This industry is characterized by bank transactions by the non-appeal to the interest. Within the framework of the development of the Islamic banks everywhere worldwide, we observe unusual growth rates in the industry. Understand "the banking performance" and "its determiners" becomes an important stake. The customers ask for a performance of the Islamic banks equal at least in that of the conventional banks. The customers do not accept any more the argument according to which the Islamic banks offer products compatible with the Sharia but more expensive. Furthermore, the competition coming from departments Islamic established by the conventional banks obliges the Islamic banks to take rigorous measures in sight to improve their performance and by recruiting the best capacities and skills. Define and measure the banking performance is important: in fact, the way that companies measure the performance is crucial for their survival and their progress because the performance plays a very important role in the development of the strategic plans in the evaluation of the organizational objectives and in the payment for the managers (Ittner \& Larcker, 1997, 1998 and 2000).

The structure of the banking systems knew number of changes since the eighties. These changes are the fruit of the adaptation of banks to the new order of financial markets marked by an opening of the markets which was translated by an accentuation of the competition. The banking performance is essentially represented by the quantitative indicators such as the financial indicators (ROA, ROE, etc.). The same situation tends to meet when we study "the determiners of the banking performance". Although these last ones report the banking performance, we consider that they are fragmented and thus insufficient. In this paper, we suppose that the performance of a bank, which operates in an uncertain environment and a fowl (Naylor, 1995), is certainly allocated not only by the internal variables of quantitative nature like the financial ratios but also by the internal variables of qualitative nature like variables concerning the activities or the manager preferences. This position has two consequences: to approach the question of the performance of a banking institution, it is necessary to refer to a global model which allows integrating at the same time the financial, organizational and environmental aspects. On the other hand, it is necessary that this model consider the interactions between each of these 
aspects because a bank must be conceived as a system having functions (multiple determiners) which are in interaction between them and with the environment (Schein, 1971).

Within the framework of these restructurings, measure the activity of banks as actor of the economic growth, understand their behavior and the impact of these on the variations of the profitability of the Islamic banking institutions as well as its repercussions on the whole of national economy is of a major importance. Our model goes to this direction by investigating the determiners of the profitability of a sample of the Islamic banks over the period 2012-2014 by leading an analysis of panel data. In this optics, the objective of this study is to propose a systematic model which is capable of integrating all the interrelations or still the links which can relate the banking performance and its determiners.

Within the framework of economic and financial studies, some authors were interested in the analysis of the determiners of the banking profitability in countries so developed as in process of development. Nevertheless, in the case of the golf countries, there is practically no serious study on this crucial question. The poverty of the studies on the subject may be due to the fact that the financial and banking reforms were born only late and that the access to the data concerning banks is very difficult. But, the analysis of the banking performances, in particular in terms of profitability, is of a big interest, if only to allow the banks to arrest the factors which act on their profitability and of offering them so better control levers of action, control and forecast. We suggest approaching this question from the specification and from the estimation of a model which integrates at once organizational, exogenous and macro-financial measurable aspects. Understand the banking politics requires detailed knowledge of the determiners of the profitability of banks which is the essential objective of this paper. How does the profitability of banks react to its hand determiners? How the characteristics of banks and economic and financial environment affect the profitability of the Islamic banks?

\section{Literature Review}

The review of the literature shows that the banking performance is essentially represented by the quantitative indicators such as the financial indicators. The same situation tends to meet when we study the determiners of the banking performance. 
Indeed, the literature retains essentially interns or externs variables of quantitative nature to explain the banking performance.

Nevertheless, the consensus is far from being completely gathered around the question of the impact of certain variables on the banking profitability such as it's measured. While the effect predicted by certain factors found certain unanimity within the circle of the economists, controversies at the level of the impact expected from the other variables. It is consequently justifiable to consider that theoretical debate would only be empirical.

The paragraph below explains the different potential determiners of banking profitability and thus by splitting them into organizational, macro-financial and exogenous variables while questioning their effects expected in accordance with the predictions of the economic theory and the estimations that issued from empirical studies realises in the developed countries and those in process of development.

The economic theory and the existing empirical studies often stresses on the impact of certain organizational factors on the profitability of assets. While the economic theory insists on the negative effect of the costs of banking exploitation on the profitability, some empirical studies support rather the idea than the impact may be positive (Ben Naceur, 2003); for the maximization of the profit, banks tend to engage additional exploitation expenses and so justifying the variation in the same sense between the general banking charges and the profitability of assets (Bashir, 1999; Ben Naceur, 2003).

Anghbazo (1997) and Guru \& al (2002) consider that the realization of profits cannot be made without engaging expenses. But banks have to avoid engaging expenses. The differences between the theoretical constructions and the empirical investigations are also noticed at the level of the impact of stockholders' equities on the profitability of the banking assets. Many empirical studies revealed that stockholders' equities play the role of stimulating effect on the profitability of banks (Bashir, 2000; Abrew \& Menden 2002; Ben Naceur, 2003) but the excess of capital ratio is considered as harmful to the profitability of assets because, by raising this ratio, banks tend to realize a small fruiting of current assets.

Furthermore, the other studies relative to the evaluation of the efficiency of a statutory requirement on stockholders' equities and to the determination of its clear effect on the probability of failure of the bank suggest that a constraint of heavier 
capitalization related to lower total risk. According to Avery \& Berger (1991), a hight ratio (stockholders' equities/assets) is related to lower profitability of the bankruptcy. Whereas, we can deduce a quasi-unanimity of the economists on the positive impact of the bank credits on the profitability of assets confirming the predictions of the economic theory.

The renforcement of the politics of credit raises the banking profits. In other words, more the bank acquires credits, more incomes increase and thus the profits (Bashir, 1999; Ben Naceur, 2003). Nevertheless, the politics of credit may sometimes hinder the banking profitability, in particular when an expansionist policy of credit is incompatible with the strategy pursued in search for financial resources (Bashir, 2000).

Consequently, the control of the politics of deposits should normally help the bank to increase its profits (Moulneux \& Thornton, 1992; Bourke, 1989; Ben Naceur, 2003). Concerning the bank size, by making regressions on data of panel and by expressing the profits according to a set of internal and external factors, certain authors (Bourke, 1989; Molyneux \& Thornton, on 1992) obtained a positive and statistically significant relation between the size and the profitability of assets.

Other authors (Rouabah, 2006) consider however that the size is not an opportunity for savings of the costs, so supporting the idea that the big banks are subject to ineffectivenesses of scale. The divergence between the theory and the empiricism exist also at the level of the impact of certain macro-financial variables on the profitability of assets. If the emergence of the capital markets in countries in process of developped strengthens the banking activity; as supported it recent empirical studies (Bashir, 1999; Demerguç-Kunt \& Huizinga, 2001; Rouabah, 2006; Beckman, 2007); the extension of these markets can produce an effect of replacement on the activity of banks, so contradicting the theoretical predictions (Ben Naceur, 2003). As for the banking concentration and for the size of the banking sector, their impact estimated on the profitability of the banking assets is generally positive, what confirms empirically the economic theory (Ben Naceur, 2003; Rouabah, 2006; Backman, 2007).

The financing of the economy by the banking sector reflects the capacity of the system to satisfy the needs of the economic actors. The size of sector is then sensible to benefit the various intervenors (Demerguç-Kunt \& Huizinga, 2001; Ben 
Naceur, 2003). Also, traditionally, the strategies of concentration and their developments are justified by the realization of economies of scale. The introduction of this variable empirically proved a positive relation with the return on assets (Pair of shorts, 1979; Bourke, 1989; Moulyneux \& Thornton, 1992; Demerguç-Kunt \& Huizinga, 2001).

The estimation of the impact of the macroeconomic variables, in particular the economic growth and the inflation, often found a common ground between the economists. Several authors confirm unanimously the existence of a positive relation between the economic growth and the growth of the banking profits (Bashir, 2000; Rouabah, 2006; Beckmann, 2007). In their opinion, the national wealth which benefits all the economic activity of the country, affects positively the evolution of the banking sector and incites banks to innovate and to renew their techniques and technologies of management. Concerning the impact of the variation of the general level of the prices, the works of Molyneux and Thornthon (1992), Guru and al (2002), Abreu and Mende (2002) brought clarifications on the links susceptible to exist between the return on assets and the inflation.

According to Bashir and Hassan (2003), who studied the factors which influence the profitability of the Islamic Banks in 8 countries during the period (1993-1998), assert that a high ratio of (loan / TA) results an improvement of the profitability.

Srairi (2009) and Srairi and Ben Douissa (2014) asserts that the size, the stockholders' equities, the risk of credit (loan / TA), as well as the ratio liquidity have a significantly positive relation with the profitability of the Islamic banks. On the other hand he supposes that the ROE is in a negative relation with the general Overheads (expenses / TA).

He also indicated that the ROA and the ROE are the most successful indicators to estimate the profitability of banks; the capital ratio, actif not interest and the credit risk are the significant factors, while the inflation is absolutely not significant and has only a low effect of all the other indicators of profitability

Here are the three important factors that determine the efficiency of banks:

- The importance of the capital represents the fundamental determiner of the profitability measured by the ROA. 
- The ratio (loan / TA) is statistically significant and has a positive relation with the performance of the domestic banks; so the ratio of (liquidity / Customer) indicates a negative relation.

- Finally, the 3rd factor results from the fact that the macroeconomic indicators (inflation, growth rate) are statistically significant and have a relation of efficiency with the domestic as wel as foreigner banks.

Most of the Islamic banks concentrate their performance on the satisfaction of the quality of asset and the capital.

He adapted a linear model represented by the ROA and supposes that it is the explained variable which influences the performance of the Islamic banks.

$$
R O A_{i t}=\alpha+\beta_{1} X_{i t}+\beta_{2} Z_{i t}+\varepsilon_{i t}
$$

With:

$R O A_{i t}$ : the ratio of profitability of asset,

$\alpha$ : the constant,

$X_{i t}:$ the factors explanatory,

$Z_{i t}:$ the external factors,

$\beta_{1}$ et $\beta_{2}$ : the coefficients of regression,

$\varepsilon_{i t}:$ the term of errors.

The economic literature groups together the determiners of the banking profitability in internal factors (capital, loan, liquidity, overheads, ....) and external factors (growth rate, inflation rates, ...) to the bank. The estimation of most of the internal factors indicated by the literature is made with difficulty generalizable data. Indeed, we can find data for a given zone which are not comparable in a international way (Haslam, 1968). Other variables for which the data are available and suggested by the literature are the ratios of capital and liquidity, the losses on loans of exploitation and certain general overheads (Short, 1979). They are generally factors related to management. Concerningr the external factors, they are not directly controled by management but under the control of other institutions.

\section{Methodology}

Concerning this paper, we are going to retain the following main determiners: the manager or organizational determiners which contain the expenses of banking 
exploitation, the stockholders' equities, bank credits and the macroeconomic factors containing the economic growth and the inflation.

The organizational factors susceptible to explain the profitability of banks are constituted by the expenses of banking exploitation, stockholders' equities, bank credits and size of the bank. So, two exogenous variables of macroeconomic order were selected as potential determiners of the profitability of assets: it is about the rate of the economic growth and about the inflation rate.

We try to test the relevance of the determiners of the Islamic banks performance. To do it, we shall use in this empirical validation an econometric model of linear regression.

\subsection{Characteristics of the sample}

The sample of our study consists of 10 Islamic Banks, belonging to the various countries (Sudan, Saudi Arabia, Bahrain, Turkey, Lebanon, Mauritania, Pakistan, Tunisia, Emirate and Qatar). The information used are mainly financial status grouping together balance sheet result account concerning a period of 3 years going from 2012 to 2014.

\subsection{Presentation of the model}

The model appears as follows:

$$
R O A_{i t}=\alpha+\alpha_{1} C T A_{i t}+\alpha_{2} P T A_{i t}+\alpha_{3} \text { ASITA }_{i t}+\alpha_{4} A L C C_{i t}+\alpha_{5} F G T A_{i t}+\alpha_{6} T X C R_{i t}+\alpha_{7} T X I N F_{i t}+\varepsilon_{i t}
$$

\section{With:}

$\mathrm{i}$ : the number of banks going from 1 to 10

$\mathrm{t}$ : the number of year going from 1 to 3

$R O A_{i t}$ : the dependent variable which represents the ratio of profitability of asset

$\alpha:$ the constant parameter of the model

$$
\begin{aligned}
& C T A=\frac{\text { stockholders equities }}{\text { Total assets }} \\
& P T A=\frac{\text { Loan }}{\text { Total assets }} \\
& A S I T A=\frac{\text { Asset without int errest }}{\text { Total assets }} \\
& A L C C=\frac{\text { Liquidity }}{\text { Customer debt }}
\end{aligned}
$$


$F G T A=\frac{\text { General overheads }}{\text { Total assets }}$

$T X C R_{i t}$ : Inflation rate

TXINF $_{i t}:$ Growth rate

$\varepsilon_{i t}:$ the error term

This model presents an explained endogenous varible and seven exogenous explanatory variables. It is thus a question of analyzing the influence of these seven explanatory variables on the dependent variable. The estimation of this model by the method of less squared common is made for the software STATA 8.

\subsection{Description of variables}

The descriptive statistics of variables are shown in table 1.

\begin{tabular}{|c|c|c|c|c|c|}
\hline Variables & $\begin{array}{l}\text { Observati } \\
\text { ons }\end{array}$ & Mean & Min & Max & $\begin{array}{r}\text { Standar } \\
\text { d deviation }\end{array}$ \\
\hline & 30 & 0.026273 & 0.0007 & 0.0837 & 0.021473 \\
\hline ROA & \multicolumn{2}{|c|}{3} & & \multicolumn{2}{|c|}{6} \\
\hline CTA & 30 & 0.26411 & 0.0682 & 0.8368 & 0.216386 \\
\hline \multirow[t]{2}{*}{ PTA } & 30 & 2.094488 & 0.0271 & 46.18 & 8.330384 \\
\hline & \multicolumn{2}{|c|}{7} & & & \\
\hline ASITA & 30 & 0.001715 & 0.00005 & 0.0099 & 0.002317 \\
\hline \multirow[t]{2}{*}{ ALCC } & 30 & 0.299473 & 0.0213 & 0.7284 & 0.243386 \\
\hline & \multicolumn{2}{|c|}{3} & & \multicolumn{2}{|r|}{1} \\
\hline FGTA & 30 & 0.000405 & 0.00014 & 0.0007 & 0.000193 \\
\hline \multirow[t]{2}{*}{ TXCR } & 30 & 0.06609 & 0.03 & 0.1012 & 0.020247 \\
\hline & & & & \multicolumn{2}{|r|}{5} \\
\hline \multirow[t]{2}{*}{ TXINF } & 30 & 0.0558 & 0.02 & 0.0965 & 0.025551 \\
\hline & & & & \multicolumn{2}{|r|}{4} \\
\hline
\end{tabular}

Now, it's necessary to study the matrix of correlation of variables:

$$
\text { IROA ROE CTA PTA ASITA ALCC FGTA TXCR TXIN }
$$




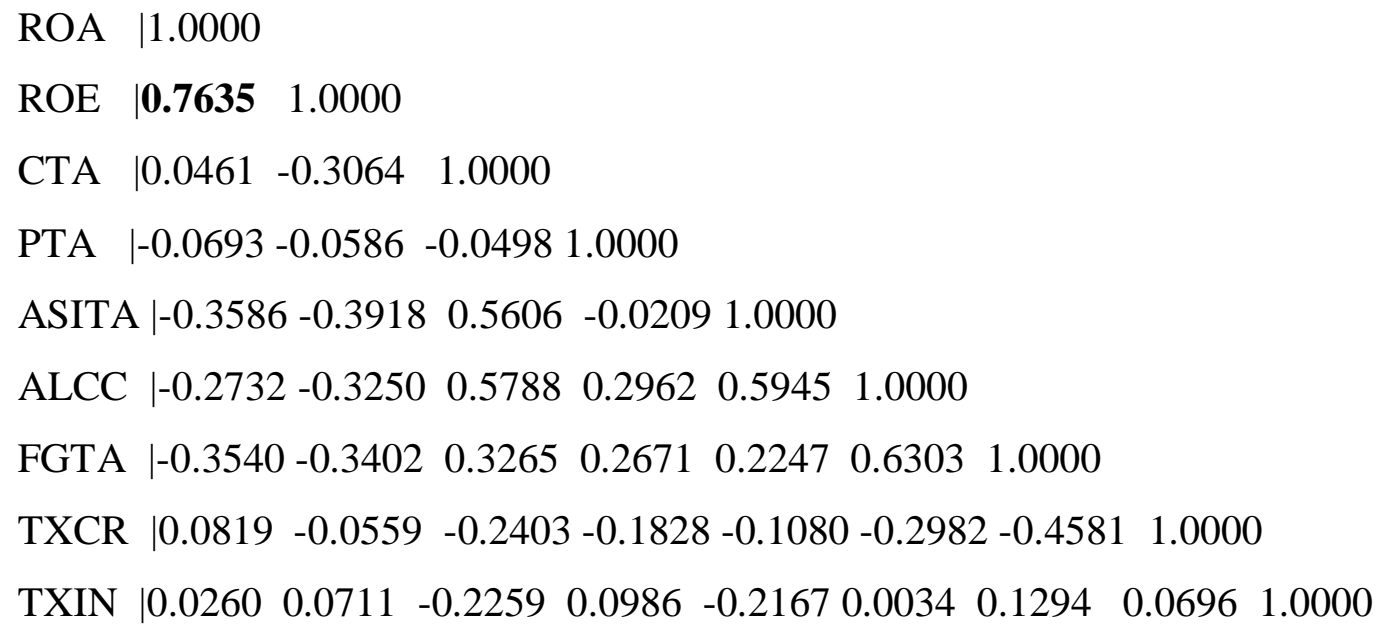

Indeed, this board presents the correlations between the various variables of our model. The level of correlation between variables is low. However, we notice that both dependent variables are positively correlated between them with a coefficient of (0.7635).

\section{Results and Discussion}

Having made a regression of the explained variable (ROA) on the explanatory variables, the results appear as follows:

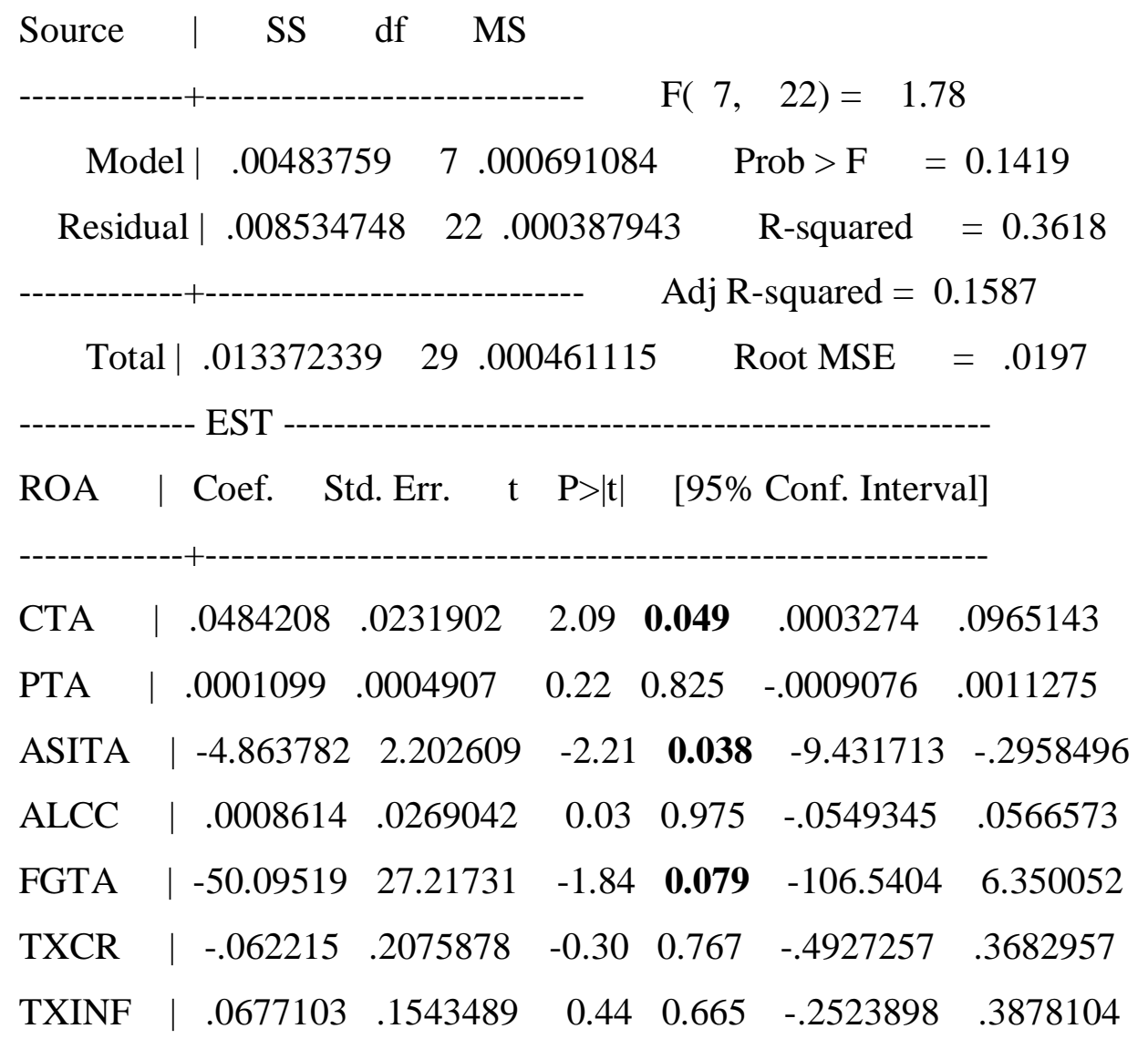


Vol. 2, No. 1 (Jun 2018); ISSN: 2602-5655

\begin{tabular}{l|llllll} 
cons & .0419601 & .020886 & 2.01 & 0.057 & -.0013548 & .085275
\end{tabular}

Table 2 shows that CTA, PTA, ALCC and TXINF have a positive effect contrary to ASITA, FGTA and TXCR which affect negatively ROA.

With the aim of analysis of the determiners of the Islamic banking performance, the estimation of the proposed static model indicates that the least successful Islamic Banks are the ones who possess loans andlor liquidity assets. The second result is that the effects of the rates of growth and inflation are not significant on Islamic Banks performance.

According to this model, the obtained results also showed that the profitability of asset (ROA) constitutes the main explanatory variable of the level of the banking performance.

\section{Conclusion and Recommendations}

This paper focus on the analysis of the financial situation of the Islamic banks through a determination of factors which can influence the performance or the profitability of banks. As basic information, we used the data concerning the financial status of the Islamic banks to calculate ratios allowing an interesting analysis of the state of these establishments being that they consist in particular in supplying useful informationfor taking economic decisions on the financial situation. The performance and the way with which a financial institution obtained and spent some liquidity assets, help us to have an idea on the profitability of these establishments.

So that the informations supplied by financial status and ratios are sincere and clear and to assure the perpetuity of banks, we applied a qualitative approach which aims at estimatin if the organization and the functionings are adopted well in the activities which it exercises and at the risks which it incurs.

But we found that even if we identified the financial situation it remains insufficient seen the presence of the factors which can affect the banking profitability, and here arrives the role of our empirical study when we tried to determine the influence of certain factors on the situation (profitability) of an Islamic Bank.

The econometric model which, in spite of in the difficulty of collection of information (10 banks and for a period of 3 years), allowed to study the impact of the internal and external factors on the fiability and the performance of the Islamic Banks. The results were not all corresponding in the theoretical prediction. 
Vol. 2, No. 1 (Jun 2018); ISSN: 2602-5655

\section{REFERENCES}

Abreu, M. et Mendes, V. (2002). "Commercial Bank Interest Margins and Profitability: Evidence from E.U Countries", Porto Working paper series.

Anghbazo, L. (1997). “Commercial Bank Net Interest Margins, Default Risk, InterestRate Risk, and Off-Balance Sheet Banking 1989-2003, Journal of Banking and Finance, Vol.2, pp.155-87.

Avery, Robert, and Allen Berger, (1991). "Risk-Based Capital and Deposit Insurance Reform," Federal Reserve Bank of Cleveland, Working Paper no. 91-01.

Bashir, A. (1999), 'Risk and Profitability Measures in Islamic Banks: The Case of Two Sudanese Banks', Islamic Economic Studies, 6(2), 1-24.

Bashir, A. (2000). "Assessing the Performance of Islamic Banks: Some Evidence from the Middle East 1993-1998”, Papier présenté à la 8ème Conférence de l'Economic Research Forum (ERF), Amman, Jordanie, novembre.

Beckmann, R. (2007). "Profitability of Western European Banking Systems: Panel Evidence on Structural and Cyclical Determinants; Discussion Paper Series N²: Banking and Financial Studies, No 17/2007.

Ben Naceur, S. (2003). The determinants of the Tunisian banking industry profitability: Panel evidence 1980-2000. Papier présenté à la 11ème Conférence de l'Economic Research Forum (ERF), Marrakech, novembre.

Bourke, P. (1989), 'Concentration and other determinants of bank profitability in Europe, North America and Australia', Journal of Banking and Finance, 13, 65- 79.

Dananjaya, I and Kuswanto, A (2015), Influence of External Factors on the Performance through the Network of Small and Medium Enterprises, European Journal of Business and Management. Vol $7 \mathrm{n}^{\circ} 27$. pp 38-48.

Demerguç-Kunt, A. et Huizinga, H., (2001). "Financial Structure and Bank Profitability 1990-1997“, in Asli Demirguç-Kunt and Ross Levine (eds.), Financial Structure and Economic Growth: A Cross-Country Comparison of Banks, Markets, and Development, Cambridge, MA: MIT Press.

Haslam A. (1968): "A statistical analysis of the relative profitability of commercial banks", Journal of finance. 
Vol. 2, No. 1 (Jun 2018); ISSN: 2602-5655

Hassan, M.K., Bashir, A., (2003). Determinants of Islamic Banking Profitability. Paper Presented at the Proceedings of the Economic Research Forum 10th Annual Conference, Marakesh-Morocco.

Guru B., Staunton, J. et Balashanmugam, M. (2002). "Determinants of Commercial Bank Profitability in Malaysia 1986-1995“, University Multimedia working papers/2002.

Ittner, C.D., Larcker, D.F., Meyer, M. W. (1997)»Performance, compensation, and the balanced scorecard«, Technical report, University of Pennsylvania. Molyneux, P. \& Thornton, J. (1992):"Determinants of European bank profitability: A note", Journal of banking and finance 16 .

Ittner, C.D., Larcker, D.F. (1998) »Are nonfinancial measures leading indicators for financial performance? An analysis of customer satisfaction«, Journal of Accounting Research, 36(1), pp. 21-35.

Itnner, C.D., Larcker, D.F. (2000, October 16) »Non-financial Performance Measures: What Works and What Doesn't«, Financial Times' Mastering Management series, Wharton School, Pennsylvania. Franko Milost Int.J.Buss.Mgt.Eco.Res., Vol 4(6), 2013,823-828.

Rouabah, A. (2000): "Compétitivité des banques luxembourgeoises, monnaie unique et perspectives stratégiques des acteurs". Thèse de Doctorat es sciences de Gestion, Université de Nancy 2.

Srairi, S., (2009), A comparison of the profitability of Islamic and conventional banks: The case of GCC countries, Bankers, Markets, Investors, 34, pp.45-62.

Srairi, S., Ben Douissa, I., (2014), Factors influencing bank transparency: Case of emerging markets, British Journal of Economics, Management and Trade, 4, pp.523-540.

Schein, E.H. (1971). «The individual, the organization, and the career: A conceptual scheme», The Journal of Applied Behavioral Science, Vol. 7, nº4, p. 401-426.

Short, B. K. (1979). “The Relation Between Commercial Bank Profit Rates and Banking Concentration in Canada, Western Europe and Japan”, Journal of Banking and Finance, Vol. 3.

\section{Entire Web site}

www.islamic-banking.com

$\underline{\text { www.fleursd'Islam.com }}$ 
www.ribh.info

www.agefi.lu/mensuel/Article

www.Firdaous.com

www.globenet.org.

www.aljamaa.net/fr/detail-khabar.asp

www.aljamaa.net/fr/detail-khabar.asp

www.agefi.lu/mensuel/Article

$\underline{\text { www.lamicrofinance.org }}$

www.aljamaa.net/fr/detail-khabar.asp 